\title{
UNDER THE MICROSCOPE
}

Jose M. Carnate, Jr., MD¹ Audie G. Silva, MD²

\section{'Department of Pathology}

College of Medicine- Philippine General Hospital

University of the Philippines Manila

${ }^{2}$ Department of Laboratories

Philippine General Hospital

University of the Philippines Manila

Correspondence: Jose M. Carnate, Jr., MD

University of the Philippines Manila

College of Medicine

Department of Pathology

547 Pedro Gil St., Ermita, 1000 Manila

Phone: (632) 5264550

Fax: (632) 4003638

Email:jmcjpath@yahoo.com

Reprints will not be available from the author.

\section{Granular Cell Tumor Presenting as a Tracheal Mass in a 17-Year- Old Female}

Granular cell tumors involving the trachea are rare. We present the case of a 17-year-old female with a one year history of gradually worsening dyspnea necessitating a tracheotomy. A suprastomal intraluminal tracheal mass was excised. Histologic sections (Figure 1) show a poorly circumscribed neoplasm infiltrating through the tracheal cartilage. It is composed of polygonal to somewhat elongated tumor cells that have small, dark nuclei. The cytoplasm is ample, eosinophilic and strikingly granular in quality.

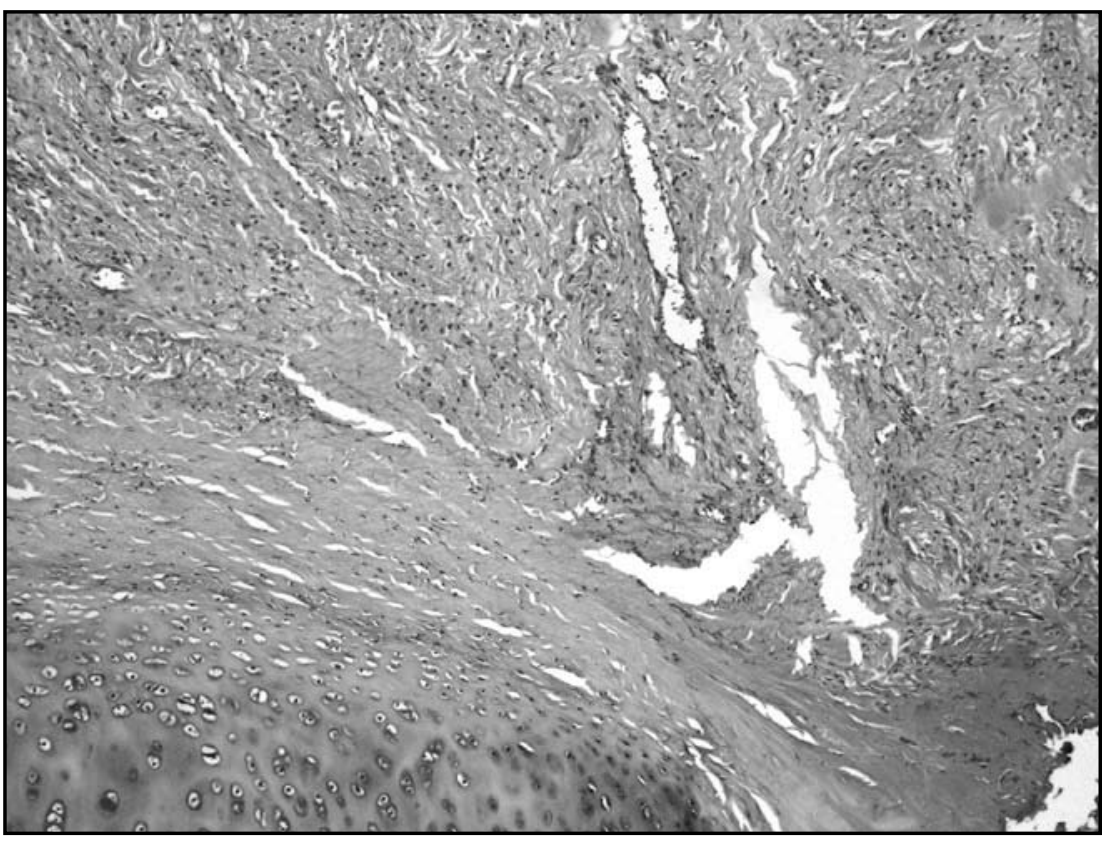

FIGURE 1 


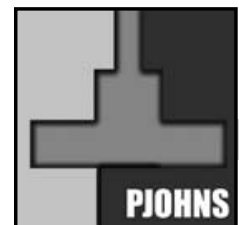

\section{UNDER THE MICROSCOPE}

Philippine Journal Of Otolaryngology-Head And Neck Surgery

VOL. 23 No. 1 JANUARY - JUNE 2008

The cell borders are ill-defined creating a 'syncytial' pattern of dark nuclei scattered in a sea of granular cytoplasm. (Figure 2) The diagnosis was a granular cell tumor. Immunohistochemistry (Figure 2, inset) revealed diffuse strong cytoplasmic positivity for S100 protein, attesting to its neural crest histogenesis. The infiltrative growth pattern may momentarily raise the question of malignancy but this is dispelled by awareness that infiltration is the natural history for all granular cell tumors, benign or malignant. Histologically, malignancy is diagnosed if three or more of the following are present: necrosis, spindling of tumor cells, vesicular nuclei with large nucleoli, greater than two mitoses per 10 high power fields, high nucleus-to-cytoplasm ratio and nuclear pleomorphism. None was present in our case. Surgical excision remains the mainstay of treatment.

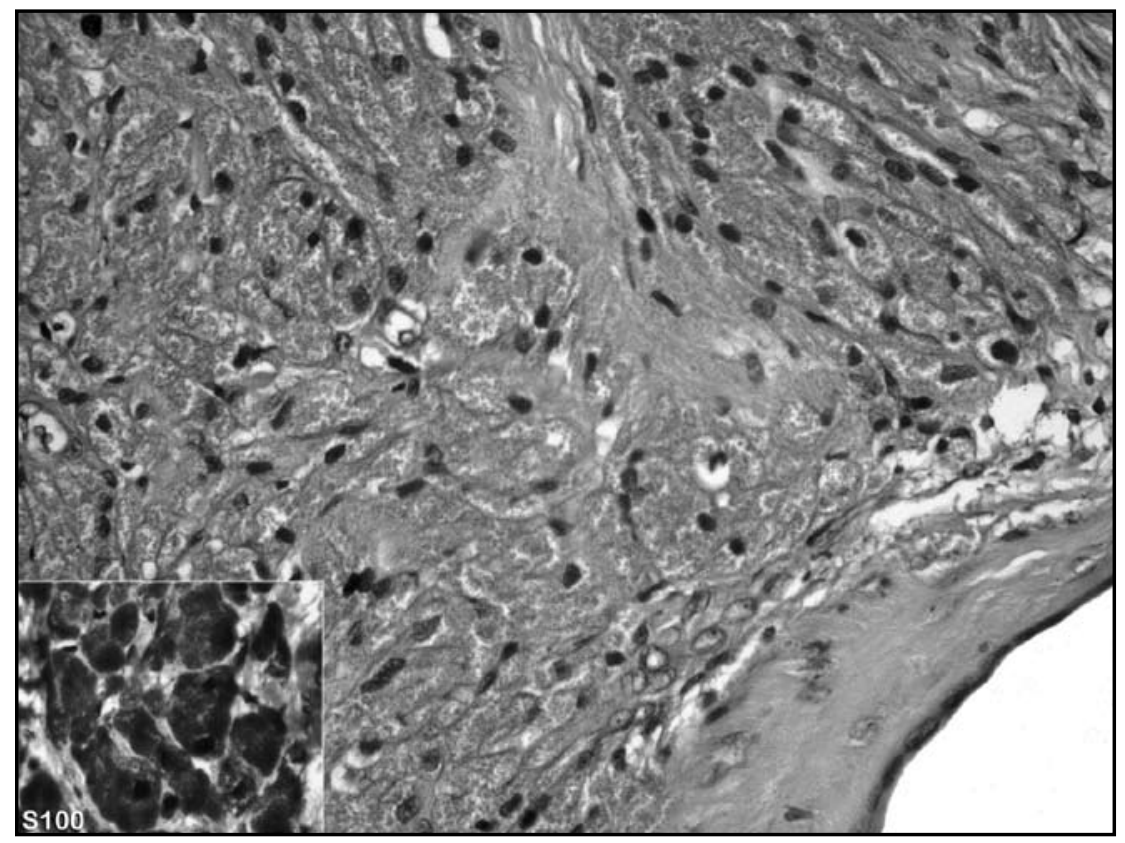

FIGURE 2

\section{REFERENCES:}

1. Van der Maten J, et al. Granular cell tumors of the tracheobronchial tree. JThorac Cardiovasc Surg 2003; 126: 740 - 3.

2. Fanburg-Smith JC, et al. Malignant granular cell tumor of soft tissue: diagnostic criteria and clinicopathologic correlation. Am J Surg Pathol 1998; 22 (7): 779 $-94$.

3. Barnes L, Eveson JW, Reichart P, Sidransky D (Eds).: World Health Organization Classification of Tumours. Pathology and Genetics of Head and Neck Tumours. IARC Press: Lyon 2005. 